\title{
Quantitative infrared absorption cross sections of isoprene for atmospheric measurements
}

\author{
C. S. Brauer ${ }^{1}$, T. A. Blake ${ }^{1}$, A. B. Guenther ${ }^{2}$, S. W. Sharpe ${ }^{3}$, R. L. Sams ${ }^{1}$, and T. J. Johnson ${ }^{1}$ \\ ${ }^{1}$ Physical Sciences Division, Pacific Northwest National Laboratory, P.O. Box 999, Richland, WA 99352, USA \\ ${ }^{2}$ Atmospheric Sciences and Global Change Division, Pacific Northwest National Laboratory, P.O. Box 999, Richland, \\ WA 99352, USA \\ ${ }^{3}$ Signature Science and Technology Division, Pacific Northwest National Laboratory, P.O. Box 999, Richland, \\ WA 99352, USA
}

Correspondence to: C. S. Brauer (carolyn.brauer@pnnl.gov)

Received: 30 March 2014 - Published in Atmos. Meas. Tech. Discuss.: 25 April 2014

Revised: 16 September 2014 - Accepted: 30 September 2014 - Published: 19 November 2014

\begin{abstract}
Isoprene $\left(\mathrm{C}_{5} \mathrm{H}_{8}, 2\right.$-methyl-1,3-butadiene $)$ is a volatile organic compound (VOC) and is one of the primary contributors to annual global VOC emissions. Isoprene is produced primarily by vegetation as well as anthropogenic sources, and its $\mathrm{OH}$ - and $\mathrm{O}_{3}$-initiated oxidations are a major source of atmospheric oxygenated organics. Few quantitative infrared studies have been reported for isoprene, limiting the ability to quantify isoprene emissions via remote or in situ infrared detection. We thus report absorption cross sections and integrated band intensities for isoprene in the $600-6500 \mathrm{~cm}^{-1}$ region. The pressure-broadened (1 atmosphere $\mathrm{N}_{2}$ ) spectra were recorded at 278,298 , and $323 \mathrm{~K}$ in a $19.94 \mathrm{~cm}$ path-length cell at $0.112 \mathrm{~cm}^{-1}$ resolution, using a Bruker IFS 66v/S Fourier transform infrared (FTIR) spectrometer. Composite spectra are derived from a minimum of seven isoprene sample pressures, each at one of three temperatures, and the number densities are normalized to $296 \mathrm{~K}$ and $1 \mathrm{~atm}$.
\end{abstract}

\section{Introduction}

The primary biogenic sources of isoprene include trees, mosses, and ferns, as well as animals and microbes. Isoprene also is produced commercially as a reagent in the production of synthetic rubber and aviation fuel and is emitted from the combustion of fossil fuel and biomass burning (Akagi et al., 2013; Hess et al., 2013). The amount of isoprene produced by non-biogenic processes, however, is only $0.1 \%$ of the
$600 \mathrm{Tg}$ annual production estimated from living organisms (Hess et al., 2013; Guenther et al., 2012). Annual global isoprene emissions account for approximately one-third of total volatile organic compounds (VOCs), with methane contributing an additional third, and hundreds of other VOCs comprising the remainder of emissions (Guenther et al., 2012). Isoprene and other VOCs are of interest because of their role in mediating atmospheric oxidants and aerosol production. The limited knowledge of isoprene emissions, distributions, and transformations (primarily due to a lack of measurements) is a major contributor to uncertainties in model simulations of regional air quality and global climate (Guenther et al., 2012)

Isoprene measurements are also of interest to characterize important biological processes. Isoprene concentrations in human breath, for example, vary from tens to hundreds of ppbv ( $1 \mathrm{ppbv}=1 \mathrm{nmol}$ of analyte per mole of air) and have been used as an indicator of high blood cholesterol levels (Karl et al., 2001). In addition, isoprene may be a harbinger of stress in plants. For example, the foliage of some plants emit isoprene at high rates, and isoprene appears to have a role in protection from heat stress (Sharkey and Singsaas, 1995) and possibly as a general protective mechanism for abiotic stress (Vickers et al., 2009).

Given that isoprene plays such an important role in the Earth system, it is not surprising that considerable effort has been made to develop analytical approaches for detecting and quantifying isoprene emissions. The techniques that have commonly been used include gas chromatography (GC) coupled with detection systems such as reduction gas, flame ion- 
ization, or photoionization detectors, or mass spectrometers (Kim et al., 2013). More recently, continuous fast response detectors based on chemiluminescence and proton transfer reaction mass spectroscopy have increasingly been used for concentration and eddy covariance emission measurements on towers and aircraft (Potosnak et al., 2014; Karl et al., 2013). A number of studies have utilized infrared (IR) spectroscopy for stand-off detection of isoprene (Akagi et al., 2014); however, accurate quantification of these measurements is often hindered by a dearth of high-quality quantitative reference measurements. As a result, indirect methods are often employed in order to infer isoprene emissions. For example, satellite data on the isoprene oxidation product formaldehyde (HCHO) have been used in numerous studies (see Stavrakou et al., 2009, and references therein). This approach, however, is limited by the large uncertainties in accounting for the chemical and dynamical processes relating isoprene to formaldehyde (Barkley et al., 2012). The ability to detect isoprene using satellite sensors has the potential to transform the research community seeking to quantify emissions of this important trace gas, and preliminary observations have indicated that isoprene may be detected from space by the Earth-observing Tropospheric Emission Spectrometer (TES) satellite (D. Fu, personal communication, 2013). The versatility of IR, which enables remote as well as in situ sensing, gives it a decided advantage over techniques such as chemiluminescence and mass spectrometry, which are strictly point-sensing methods.

Despite the obvious need for quantitative infrared data and the potential for infrared observation of isoprene, as well as the relative abundance of UV cross sections (e.g., Campuzano-Jost et al., 2004, 2000), the only quantitative infrared intensity studies of isoprene found in the literature report absorption cross sections in the near-infrared (Denzer et al., 2011; Cias et al., 2007). While it is not unusual to record quantitative measurements of isoprene in conjunction with other experiments or for calibration purposes, these results are seldom reported in the literature. For example, Jobson et al. (1994) used infrared spectroscopy in conjunction with gas chromatography to quantify isoprene along with $\mathrm{C}_{2}-\mathrm{C}_{5}$ alkane mixing ratios at a remote boreal site but did not directly report their infrared band strengths or cross sections. Quantitative Fourier transform infrared (FTIR) spectra of isoprene and isoprene- $d_{2}$ also were measured by Kühnemann et al. (2002) in order to determine the detection limits of isoprene using infrared photoacoustic spectroscopy.

Nonetheless, there is an abundance of studies on the vibrational spectra of isoprene, but most have focused on elucidating the structure and identifying its conformational equilibria (Compton et al., 1976; Traetteberg et al., 1984; Bock et al., 1987; Bock and Panchenko, 1989; Panchenko et al., 2008); fundamental modes typically were assigned during the structural analyses. Based on these previous vibrational assignment studies and structural determinations, and the need for quantitative absorption cross-section data, this paper makes the first comprehensive report of the infrared band strengths of isoprene.

The results reported here are based on data contained within the quantitative Northwest Infrared (NWIR; http:// nwir.pnl.gov) database (Sharpe et al., 2004; Johnson et al., 2010), which contains spectra of common atmospheric gases, toxic industrial chemicals, and species known or suspected as biomass burning effluents, degradation products, or precursors. Recent studies have included quantitative band strengths of $\mathrm{HNCO}$ (Roberts et al., 2010), $\mathrm{H}_{2} \mathrm{O}_{2}$ (Johnson et al., 2009), and glycolaldehyde (Johnson et al., 2013), as well as the dicarbonyls glyoxal, methylglyoxal, and diacetyl (Profeta et al., 2011). The availability of the quantitative band strengths allows evaluation programs such as MALT (Multiple Atmospheric Layer Transmission) (Griffith, 1996) to extract the mixing ratios and, ultimately, the emission factors (EFs, grams of effluent per kilogram of fuel) of biomass burning effluents; using the quantitative absorption cross-section information in the database and field measurements from either airborne or land-based systems, the EFs of dozens of species have been extracted in laboratory burns (Burling et al., 2010), as well as from prescribed fires in the US southwest (Akagi et al., 2011) and the US southeast (Burling et al., 2011; Akagi et al., 2013), including using open-path FTIR systems (Akagi et al., 2014). Some of these seminal EF measurements from the prescribed burns used the quantitative NWIR laboratory measurements of the related terpene species, such as limonene, as well as both $\alpha$ and $\beta$-pinene for first observation of such species in biomass burning plumes (Burling et al., 2011; Akagi et al., 2013). In addition, results included in the database have been utilized by Adler et al. (2010) in the analysis of isoprene in human breath using a broadband frequency comb.

\section{Experimental}

Broadband infrared spectra were recorded with a Bruker IFS 66v/S Fourier transform spectrometer (FTS), located at the Pacific Northwest National Laboratory (PNNL; Sharpe et al., 2004), which had been modified to include a second aperture to reduce ghosting and warm aperture effects (Johnson et al., 2002). The instrumental parameters are summarized in Table 1 and consisted of typical mid-IR (600 to $6500 \mathrm{~cm}^{-1}$ ) components, including a glow bar light source, a $\mathrm{Ge}$ on $\mathrm{KBr}$ beamsplitter, and a photoconductive $\mathrm{HgCdTe}$ detector $(77 \mathrm{~K})$. The scanner velocity was $60 \mathrm{kHz}$ (HeNe fringe crossings $\mathrm{s}^{-1}$ ), and the instrument resolution was set to $0.112 \mathrm{~cm}^{-1}$ (instrument resolution is defined here as $0.9 /$ maximum optical path difference or $0.9 / \mathrm{MOPD}$ ). Interferograms were recorded and co-added and transformed using a Cooley-Tukey fast Fourier transform (FFT) algorithm with boxcar apodization. Phase correction was performed using the Mertz method (Mertz, 1967), with a phase resolution of $4 \mathrm{~cm}^{-1}$; and the high/low folding limits were 
Table 1. Instrumental parameters for the isoprene measurements.

\begin{tabular}{|c|c|}
\hline & Instrument and absorption cell \\
\hline Spectral range & 6500 to $600 \mathrm{~cm}^{-1}(1.534$ to $16.667 \mu \mathrm{m})$ \\
\hline Instrument resolution & $0.112 \mathrm{~cm}^{-1}(0.9 / \mathrm{MOPD})$ \\
\hline Apodization & Boxcar \\
\hline Zero-fill factor & $1 \times($ Bruker setting $2 \times)$ \\
\hline Phase correction & Mertz \\
\hline Beamsplitter & $\mathrm{Ge}$ on $\mathrm{KBr}$ \\
\hline IR source & Silicon carbide glow bar $(22 \mathrm{~V})$ \\
\hline Scanner velocity & $60 \mathrm{kHz}$ (HeNe crossing frequency) \\
\hline Cell windows & 2 in. dia. wedged $\mathrm{KBr}$ \\
\hline Cell ballast pressure $\left(\mathrm{N}_{2}\right)$ & $760 \pm 5$ Torr $\left(\mathrm{UHP}_{2}\right)$ \\
\hline Detector & $\begin{array}{l}\text { Mid-band } \mathrm{HgCdTe} \text {, photoconductive, } \\
77 \mathrm{~K} \text { operation }\end{array}$ \\
\hline Folding limits & 15798 to $0 \mathrm{~cm}^{-1}$ \\
\hline
\end{tabular}

set to 15798 and $0 \mathrm{~cm}^{-1}$, respectively. A zero-fill factor of $2 \times$ (per Bruker definition) was used such that the raw single beam spectra recorded at $0.112 \mathrm{~cm}^{-1}$ had a point spacing of $0.06 \mathrm{~cm}^{-1}$. A software correction was applied to account for the nonlinear response of the mercury cadmium telluride (MCT) detector (Keens and Simon, 1990). Bruker's OPUS software was used to operate the spectrometer, collect and perform the FFT, and perform the initial data reduction.

The optics bench of the spectrometer was evacuated in order to minimize water vapor and carbon dioxide gas absorptions. Air was removed from the isoprene samples (Aldrich, $99 \%$ ) by multiple freeze-pump-thaw cycles on a vacuum manifold connected directly to the gas cell in the spectrometer. A 2-inch diffusion pump, which is attached to the manifold and the gas cell $(19.94 \mathrm{~cm}$ long, wedged $\mathrm{KBr}$ windows), was used to evacuate the gas cell before subsequently filling with the isoprene vapor. The gas cell is jacketed in such a manner that fluid from a circulation bath (Julabo F25) was used to temperature-stabilize the cell. The pressure for each sample, which is listed in Table 2, was measured with a high-precision capacitance manometer (MKS 690A series Baratron). The cell was then backfilled to a pressure of $760 \pm 5$ Torr with high purity dry nitrogen. A background spectrum with the cell filled only with $\mathrm{N}_{2}$ was recorded at each temperature, typically averaging 512 interferograms. Two-hundred fifty-six interferograms were averaged for each sample spectrum. Spectra were recorded for 7 sample pressures with the cell stabilized at $278.20 \pm 0.02 \mathrm{~K}, 10$ samples at $298.18 \pm 0.02 \mathrm{~K}$, and 7 samples at $323.12 \pm 0.02 \mathrm{~K}$. In order to exploit the full dynamic range of the instrument, a broad range of sample pressures was used. A dataweighting scheme is described below.

Each absorbance spectrum was calculated as $-\log _{10}\left(I_{\text {sample }} / I_{\text {background }}\right)$. Individual spectra, recorded at each cell temperature, were combined into a composite spectrum by plotting the absorbance vs. the isoprene concentrations for each wavenumber bin in the measured spectra. The absorption coefficient, $\varepsilon(v)$, is given by the fitted slope of the linear plot for each sample pressure, $C_{i}$, and path length, $\ell$, at each wavenumber bin, $v$ (Sharpe et al., 2004; Chu et al., 1999), viz.

$A_{i}(\nu)=\varepsilon(v) \ell C_{i}$.

However, in order to minimize various nonlinearities associated with all absorption measurements, each absorbance value was weighted by $T^{2}(v)$, where $T$ is the transmittance. Absorbances, $A_{i}>1.6$, were simply given a weight of 0 (Sharpe et al., 2002; Chu et al., 1999). The nonlinearity correction removes most of the effects due to deviations from Beer's law, but the magnitude of the deviation can still be extracted from statistical uncertainty of the fit of the slope for the absorption coefficient at each wavelength bin. See Fig. 1 for a representative plot corresponding to the absorption coefficient at $992.20 \mathrm{~cm}^{-1}$. The uncertainties arise from baseline drift, contaminant features, etc., but still tend to be larger for larger absorption coefficient, and, in general, such errors are on the order of $2-3 \%(2 \sigma)$ (Sharpe et al., 2003). The resulting composite spectrum for each temperature is effectively a plot of $\varepsilon(v)$ for a molecule number density that has been normalized to $296 \mathrm{~K}$. The composite spectra available on the website (http://nwir.pnl.gov) have wavenumber $\left(\mathrm{cm}^{-1}\right)$ units on the abscissa, and the ordinate is in units of (ppm m) $)^{-1}$ with $\log _{10}$ absorbance. Conversion factors between PNNL decadic units of $(\mathrm{ppm} \mathrm{m})^{-1}\left(\log _{10}\right)$ at $1 \mathrm{~atm}$ and $296 \mathrm{~K}$ and common Naperian absorbances are

$$
\begin{aligned}
& 1 \mathrm{ppm}^{-1} \mathrm{~m}^{-1}\left(\log _{10} \text { at } 1 \mathrm{~atm}, 296 \mathrm{~K}\right) \\
& =9.287 \times 10^{-16} \mathrm{~cm}^{2} \text { molecule }{ }^{-1}\left(\log _{e}\right) \text {, } \\
& 1 \mathrm{ppm}^{-1} \mathrm{~m}^{-1}\left(\log _{10} \text { at } 1 \mathrm{~atm}, 296 \mathrm{~K}\right) \\
& =2.303 \times 10^{4} \mathrm{~cm}^{-1} \mathrm{~atm}^{-1}\left(\log _{e}\right) \text {. }
\end{aligned}
$$

Integrated band intensities reported in the present work have been converted to units of $\mathrm{cm}$ molecule ${ }^{-1}$ with $\log _{e}$ absorbances. The fitting process for producing the composite spectrum also calculates an uncertainty from the fit for each wavenumber bin. This resulting uncertainty vector describes the random (NIST (National Institute of Standards and Technology) type-A) uncertainties of the measurements. The average type-A uncertainties are $0.76,0.26$, and $0.93 \%$ for the spectra taken at 278,298 and $323 \mathrm{~K}$, respectively.

Systematic (NIST type-B) errors contribute the greatest uncertainty in the absorption coefficients. Following the methodology of Chu et al. (1999) and Sharpe et al. (2002), an upper limit for the systematic error is calculated based on the maximum uncertainty of experimental parameters, viz.

$\mu_{\mathrm{B}}=k\left[\left(\mu_{\mathrm{L}}\right)^{2}+\left(\mu_{\mathrm{T}}\right)^{2}+\left(\mu_{\mathrm{P}}\right)^{2}+\left(\mu_{\mathrm{I}}\right)^{2}+\left(\mu_{\mathrm{NL}}\right)^{2}\right]^{1 / 2}$,

where $\mu_{\mathrm{L}}, \mu_{\mathrm{T}}, \mu_{\mathrm{P}}, \mu_{\mathrm{I}}$, and $\mu_{\mathrm{NL}}$ represent the path length, temperature, pressure, baseline drift of the spectrometer, and nonlinear response of the detector. The value $k=2$ is chosen 
Table 2. Sample conditions for the isoprene measurements.

\begin{tabular}{clc}
\hline Temperature (K) & Sample pressures (torr*) & Path (cm) \\
\hline 278.20 & $1.11967,2.2927,3.3006,5.2524,10.6412,21.25,45.24$ & 19.94 \\
298.18 & $0.89149,1.06447,2.7667,4.0640,4.9813,6.2751,14.21,21.45,39.52,70.97$ & 19.94 \\
323.12 & $1.02313,2.2577,3.1556,5.3804,10.3506,21.09,42.38$ & 19.94 \\
\hline
\end{tabular}

$* 760$ torr $=1013 \mathrm{hPa}$

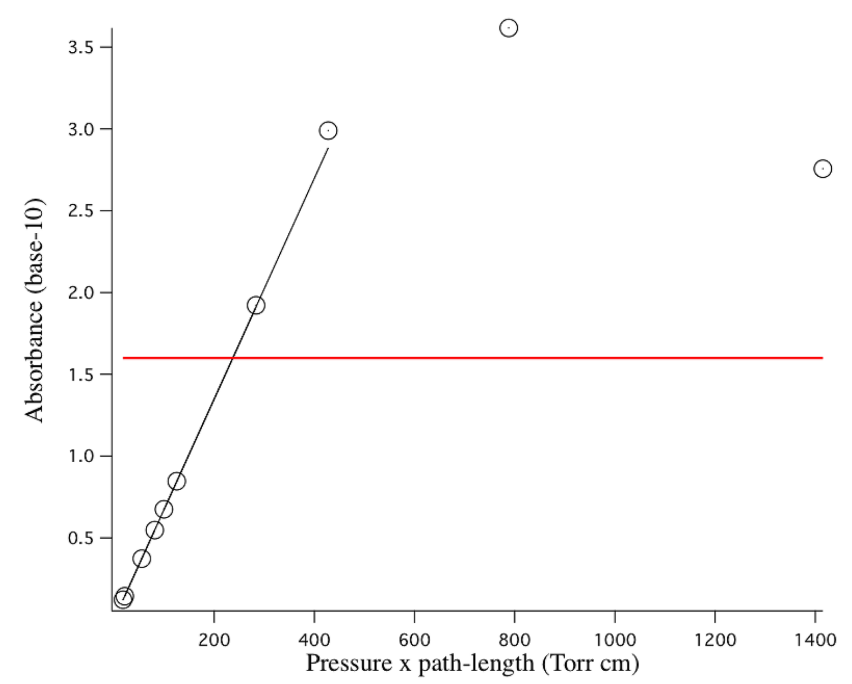

Figure 1. Absorbance versus (pressure $\times$ path length) corresponding to the wavenumber value at $992.20 \mathrm{~cm}^{-1}$. The horizontal red line designates an absorbance value of 1.6 , above which the weighting coefficients are set to 0 . The slope of the black line is the fitted absorbance coefficient for the point at $992.20 \mathrm{~cm}^{-1}$.

at the $95 \%$ confidence limit $(2 \sigma)$. Using the experimental uncertainties listed in Table 3, a type-B (systematic) error, $\mu_{\mathrm{B}}$, is calculated to be $3 \%$ for these static-system measurements. It is assumed that the experimental uncertainties are uncorrelated, and the uncertainty is assumed to be $3 \%$ in the evaluation of the errors when discussing results for the various bands.

\section{Results and discussion}

\subsection{Vibrational assignments}

The ground-state configuration of isoprene, shown in Fig. 2a, has been established to be planar s-trans (Lide and Jen, 1964). While the consensus in the literature supports this conclusion, there has been some dispute regarding the scis conformer (Fig. 2b), its fractional abundance at room temperature, and whether the conformer is planar or gauche (Traetteberg et al., 1984; Bock et al., 1987; Cias et al., 2007; Panchenko et al., 2008; Panchenko and De Mare, 2008; Squillacote and Liang, 2005; Allodi et al., 2008). Compton a)
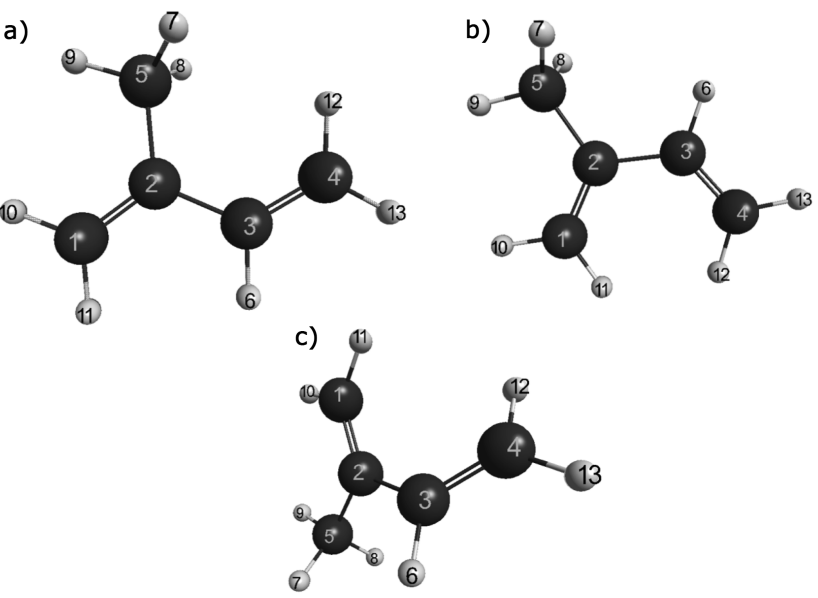

Figure 2. Isoprene in the planar s-trans (a) and s-cis (b) conformations. The gauche s-cis conformation is shown in (c), with the dihedral angle, $\mathrm{C} 1-\mathrm{C} 2-\mathrm{C} 3-\mathrm{C} 4=35^{\circ}$, corresponding to the structure calculated by Squillacote and Liang (2005) using the G3B3 method. Molecular structures were generated using the MacMolPlt graphical user interface (Bode and Gordon, 1999).

et al. (1976) studied the temperature dependence of the infrared and Raman spectra of isoprene and assigned the fundamental modes of the planar s-trans and planar s-cis conformers. The authors concluded that the planar s-cis conformation (panel b) accounted for as much as $11 \%$ and that the gauche form (Fig. 2c) was not observed.

The conformation analysis was reexamined by Traetteberg et al. (1984), who, using gas electron diffraction and theoretical techniques, determined that the gauche form did indeed exist, that it accounted for $\sim 5 \%$ at room temperature, and that the planar s-cis was unlikely to be present at all. Subsequent ab initio analyses (Bock et al., 1987; Bock and Panchenko, 1989) confirmed this, although the angle of the gauche conformer was uncertain. More recent work, including a detailed study of a series of 10 methyl-substituted 1,3-butadienes (Squillacote and Liang, 2005), established the gauche s-cis conformer of isoprene to be $2.46 \mathrm{kcal} \mathrm{mol}^{-1}$ $\left(10.29 \mathrm{~kJ} \mathrm{~mol}^{-1}\right.$ or $\left.860 \mathrm{~cm}^{-1}\right)$ less stable than the planar strans form, while the planar s-cis conformer was theoretically determined to be $3.16 \mathrm{kcal} \mathrm{mol}^{-1}$ less stable than the planar s-trans form. Thus, at the temperatures used in this work, roughly $98 \%$ of the population was in the predomi- 
Table 3. Sources of systematic uncertainties and estimated contribution to the total uncertainty.

\begin{tabular}{llc}
\hline Symbol & Parameter & $\begin{array}{c}\text { Fractional contribution to } \\
\text { parameter uncertainty }\end{array}$ \\
\hline$\mu_{\mathrm{L}}$ & Optical path length & $0.001^{\mathrm{a}}$ \\
$\mu_{\mathrm{T}}$ & Temperature & $0.001^{\mathrm{b}}$ \\
$\mu_{\mathrm{P}}$ & Pressure & $0.001^{\mathrm{a}}$ \\
$\mu_{\mathrm{I}}$ & FTIR baseline drift & $0.002^{\mathrm{c}}$ \\
$\mu_{\mathrm{NL}}$ & Detector nonlinearity & $0.015^{\mathrm{c}}$ \\
\hline
\end{tabular}

${ }^{\mathrm{a}}$ Estimated. ${ }^{\mathrm{b}}$ Manufacturer specification as a fraction of the temperature in ${ }^{\circ} \mathrm{C}$. c Measured.

nant, planar s-trans form, and our results are therefore based on that conformer.

The ground-state configuration (planar s-trans) of isoprene has $\mathrm{C}_{\mathrm{s}}$ point group symmetry. There are 33 fundamental vibrational modes, in which 22 have $\mathrm{A}^{\prime}$ and 11 have $\mathrm{A}^{\prime \prime}$ symmetry. All modes are IR active. The $\mathrm{A}^{\prime \prime}$ fundamental modes will have C-type contours (see, for example, $v_{26}$ in Fig. 5), whereas the $\mathrm{A}^{\prime}$ modes will have $\mathrm{A} / \mathrm{B}$ hybrids because the axis with the largest moment of inertia is perpendicular to the reflection plane. For isoprene, while most bands have A/B profiles, 11 have distinct $\mathrm{C}$-type contours and are readily assigned as $\mathrm{A}^{\prime \prime}$ modes.

Figures 3 through 6 show portions of our composite isoprene vapor-phase spectrum measured at $298 \mathrm{~K}$ with a quantitative $y$ axis. Frequencies and vibrational assignments are listed in Table 4. Vibrational assignments follow primarily from Panchenko et al. (2008) and Compton et al. (1976), and ab initio frequencies from Panchenko et al. (2008) also are listed for reference. Although the two sources generally agree with respect to the fundamental modes of the s-trans conformer, there are minor differences in a few of the assignments and mode descriptions. For example, Compton et al. (1976) originally assigned the peak found at $2956 \mathrm{~cm}^{-1}$, shown in Fig. 3, to an out-of-plane asymmetric $\mathrm{CH}_{3}$ stretch, $\nu_{23}$, and the peak at $2985 \mathrm{~cm}^{-1}$ to $v_{4}$, a symmetric $\mathrm{CH}_{2}$ stretch. Subsequent work (Traetteberg et al., 1984; Bock et al., 1987) was in agreement with these assignments. Panchenko et al. (2008), however, concluded that $2956 \mathrm{~cm}^{-1}$ was not a fundamental mode. Instead, $v_{23}$ was assigned to $2985 \mathrm{~cm}^{-1}$ and $v_{4}$ was assigned to $3020 \mathrm{~cm}^{-1}$ based on the vapor-phase Raman spectrum. For vapor-phase spectra, as shown in Fig. 3, however, band contours can be of great utility in assigning modes and are particularly useful in this instance. In agreement with Compton et al. (1976), the band at $2956 \mathrm{~cm}^{-1}$ is clearly a fundamental as it is the strongest $\mathrm{C}-\mathrm{H}$ band in the spectrum. Moreover, its C-type profile uniquely indicates that it is an $\mathrm{A}^{\prime \prime}$ mode, namely the highest-frequency $\mathrm{A}^{\prime \prime}$ mode, $v_{23}$, and it is assigned as such.

In the $\mathrm{C}=\mathrm{C}$ stretch region shown in Fig. 4 , $v_{9}$ is easily assigned to the A-type band at $1605 \mathrm{~cm}^{-1}$; however, $v_{8}$ is more problematic. Both Compton et al. (1976) and Panchenko

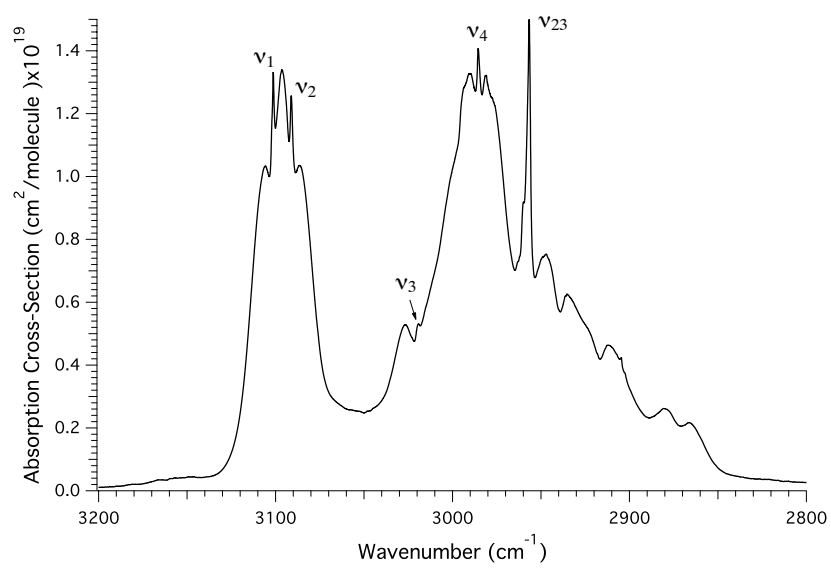

Figure 3. Quantitative infrared spectrum showing the $\mathrm{CH}$ stretch region of isoprene. Absorption cross sections are given in Naperian units $\left(\mathrm{cm}^{2}\right.$ molecule $\left.{ }^{-1}\right) \times 10^{19}$ for the composite spectrum recorded at $298 \mathrm{~K}$.

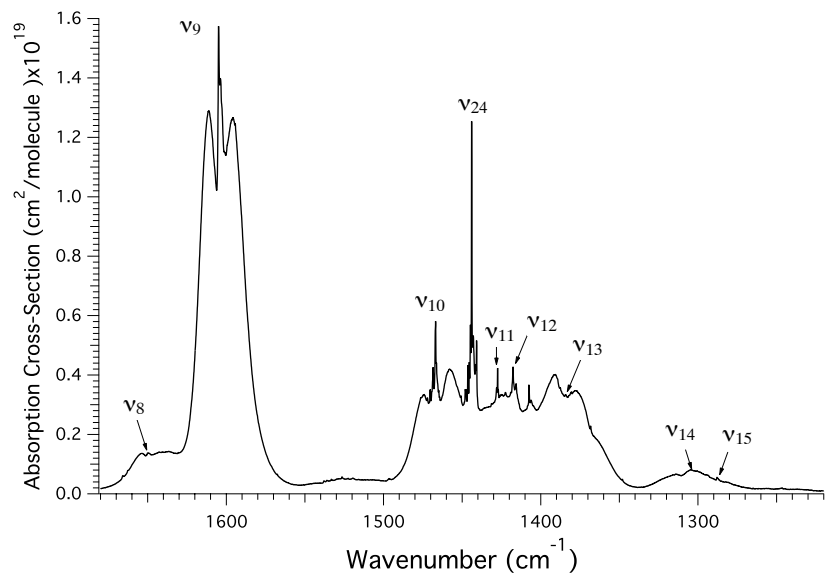

Figure 4. Quantitative infrared spectrum showing $\mathrm{C}=\mathrm{C}$ stretching and $\mathrm{CH}$ bending modes of isoprene. Absorption cross sections are given in Naperian units $\left(\mathrm{cm}^{2}\right.$ molecule $\left.{ }^{-1}\right) \times 10^{19}$ for the composite spectrum recorded at $298 \mathrm{~K}$.

et al. (2008) assign a peak at $1638 \mathrm{~cm}^{-1}$ to $v_{8}$, which was not observed in our data (see Fig. 4). Instead, a very weak A / B-type band is observed at $1651 \mathrm{~cm}^{-1}$, which we assign to the $v_{8}$ fundamental.

Finally, the $\nu_{16}$ band shown in Fig. 5 was originally assigned by Compton et al. (1976) to a very weak band at $1145 \mathrm{~cm}^{-1}$. This mode was subsequently reassigned by Traetteberg et al. (1984) to $1069 \mathrm{~cm}^{-1}$ and later assigned by Panchenko et al. (2008) to $1071 \mathrm{~cm}^{-1}$. Our assignment of $v_{16}$ at $1071 \mathrm{~cm}^{-1}$ follows Panchenko et al. (2008), and the adjacent peak at $1069 \mathrm{~cm}^{-1}$ is assigned to $\nu_{25}$.

\subsection{Integrated intensities}

Integrated intensities for isoprene, shown in Table 5, were determined using the OPUS software suite (ver. 5.5) provided 
Table 4. Vapor-phase frequencies and vibrational assignments ${ }^{\mathrm{a}}$ for observed mid-infrared bands of the planar s-trans form of isoprene.

\begin{tabular}{|c|c|c|c|c|c|}
\hline \multicolumn{2}{|c|}{$\begin{array}{l}\text { Observed frequency } \\
\qquad\left(\mathrm{cm}^{-1}\right)\end{array}$} & \multirow{2}{*}{$\begin{array}{l}\begin{array}{l}\text { Calculated frequency } \\
\left(\mathrm{cm}^{-1}\right)\end{array} \\
\mathrm{d}\end{array}$} & \multirow[t]{2}{*}{$\begin{array}{l}\text { Sym } \\
\left(C_{\mathrm{S}}\right)\end{array}$} & \multirow[t]{2}{*}{ Mode } & \multirow[t]{2}{*}{$\begin{array}{l}\text { Approximate mode } \\
\text { description }\end{array}$} \\
\hline $\mathrm{b}$ & $\mathrm{c}$ & & & & \\
\hline 3101.3 & 3101 & 3104 & $\mathrm{~A}^{\prime}$ & $v_{1}$ & $v^{\text {asy }}\left(=\mathrm{C} 4 \mathrm{H}_{2}\right)$ \\
\hline 3091.2 & 3091 & 3093 & $\mathrm{~A}^{\prime}$ & $v_{2}$ & $v^{\text {asy }}\left(=\mathrm{C} 1 \mathrm{H}_{2}\right)$ \\
\hline 3019.4 & 3017 & 3001 & $\mathrm{~A}^{\prime}$ & $v_{3}$ & $v(\mathrm{C} 3-\mathrm{H} 6)$ \\
\hline 2985.4 & - & 3018 & $\mathrm{~A}^{\prime}$ & $v_{4}$ & $v^{\text {asy }}\left(\mathrm{CH}_{3}\right)$ \\
\hline - & - & 3012 & $\mathrm{~A}^{\prime}$ & $v_{5}$ & $v^{\mathrm{sy}}\left(=\mathrm{C} 4 \mathrm{H}_{2}\right)$ \\
\hline- & - & 2996 & $\mathrm{~A}^{\prime}$ & $v_{6}$ & $v^{\mathrm{sy}}\left(=\mathrm{C} 1 \mathrm{H}_{2}\right)$ \\
\hline- & - & 2913 & $\mathrm{~A}^{\prime}$ & $v_{7}$ & $v^{\mathrm{sy}}\left(\mathrm{CH}_{3}\right)$ \\
\hline 1650.9 & - & 1646 & $\mathrm{~A}^{\prime}$ & $v_{8}$ & $v(\mathrm{C} 2=\mathrm{C} 1)$ \\
\hline 1604.9 & 1604 & 1600 & $\mathrm{~A}^{\prime}$ & $v_{9}$ & $v^{\text {asy }}(\mathrm{C} 3=\mathrm{C} 4)$ \\
\hline 1466.9 & 1467 & 1478 & $\mathrm{~A}^{\prime}$ & $v_{10}$ & $\delta^{\text {asy }}\left(\mathrm{CH}_{3}\right)$ def. \\
\hline 1427.5 & 1428 & 1435 & $\mathrm{~A}^{\prime}$ & $v_{11}$ & $\delta\left(=\mathrm{C} 4 \mathrm{H}_{2}\right)$ sci. \\
\hline 1418.8 & 1417 & 1407 & $\mathrm{~A}^{\prime}$ & $v_{12}$ & $\delta\left(=\mathrm{C} 1 \mathrm{H}_{2}\right)$ sci. \\
\hline 1384.3 & 1384 & 1371 & $\mathrm{~A}^{\prime}$ & $v_{13}$ & $\delta^{\mathrm{sy}}\left(\mathrm{CH}_{3}\right)$ def. \\
\hline 1304.6 & 1303 & 1312 & $\mathrm{~A}^{\prime}$ & $v_{14}$ & $v(\mathrm{C} 3-\mathrm{C} 2)$ \\
\hline 1288.1 & - & 1288 & $\mathrm{~A}^{\prime}$ & $v_{15}$ & $\delta(\mathrm{C} 3-\mathrm{H} 6)$ def. \\
\hline 1070.8 & 1071 & 1075 & $\mathrm{~A}^{\prime}$ & $v_{16}$ & $\rho^{\text {sy }}\left(\mathrm{CH}_{3}\right)$ rock \\
\hline 993.9 & 1003 & 1003 & $\mathrm{~A}^{\prime}$ & $v_{17}$ & $\rho\left(=\mathrm{C} 1 \mathrm{H}_{2}\right)$ rock \\
\hline- & - & 954 & $\mathrm{~A}^{\prime}$ & $v_{18}$ & $\rho\left(=\mathrm{C} 4 \mathrm{H}_{2}\right)$ rock \\
\hline 776.2 & - & 777 & $\mathrm{~A}^{\prime}$ & $v_{19}$ & $v\left(\mathrm{C} 2-\mathrm{CH}_{3}\right)$ \\
\hline - & - & 519 & $\mathrm{~A}^{\prime}$ & $v_{20}$ & $\delta(\mathrm{C} 4 \mathrm{C} 3 \mathrm{C} 2) \mathrm{def}$ \\
\hline- & - & 412 & $\mathrm{~A}^{\prime}$ & $v_{21}$ & $\delta\left(\mathrm{C} 1 \mathrm{C} 2 \mathrm{CH}_{3}\right)$ def. \\
\hline - & - & 276 & $\mathrm{~A}^{\prime}$ & $v_{22}$ & $\delta(\mathrm{C} 1 \mathrm{C} 2 \mathrm{C} 3)$ def. \\
\hline 2956.7 & 2985 & 2988 & $A^{\prime \prime}$ & $v_{23}$ & $v^{\text {asy }}\left(\mathrm{CH}_{3}\right)$ \\
\hline 1444.1 & 1444 & 1454 & $\mathrm{~A}^{\prime \prime}$ & $v_{24}$ & $\delta^{\text {asy }}\left(\mathrm{CH}_{3}\right)$ def. \\
\hline 1069.0 & 1069 & 1066 & $\mathrm{~A}^{\prime \prime}$ & $v_{25}$ & $\rho^{\text {asy }}\left(\mathrm{CH}_{3}\right)$ rock \\
\hline 991.6 & 992 & 984 & $\mathrm{~A}^{\prime \prime}$ & $v_{26}$ & $\omega(\mathrm{C} 3-\mathrm{H} 6)$ wag \\
\hline 906.3 & 906 & 902 & $\mathrm{~A}^{\prime \prime}$ & $v_{27}$ & $\omega\left(\mathrm{C} 4 \mathrm{H}_{2}\right)$ wag \\
\hline 893.8 & 894 & 898 & $\mathrm{~A}^{\prime \prime}$ & $v_{28}$ & $\omega\left(\mathrm{C}_{1} \mathrm{H}_{2}\right)$ wag \\
\hline 758.4 & - & 764 & $\mathrm{~A}^{\prime \prime}$ & $v_{29}$ & $\tau\left(=\mathrm{C} 1 \mathrm{H}_{2}\right)$ twist \\
\hline- & - & 625 & $\mathrm{~A}^{\prime \prime}$ & $v_{30}$ & $\tau\left(=\mathrm{C} 4 \mathrm{H}_{2}\right)$ twist \\
\hline- & - & 395 & $\mathrm{~A}^{\prime \prime}$ & $v_{31}$ & $\omega\left(\mathrm{C} 2-\mathrm{CH}_{3}\right)$ wag \\
\hline- & - & 200 & $A^{\prime \prime}$ & $v_{32}$ & $\tau\left(\mathrm{C} 2-\mathrm{CH}_{3}\right)$ tors. \\
\hline - & - & 157 & $\mathrm{~A}^{\prime \prime}$ & $v_{33}$ & $\tau(\mathrm{C} 2-\mathrm{C} 3)$ tors. \\
\hline
\end{tabular}

by Bruker Optics. The integration method (method A) uses 0 as the baseline and performs a numerical integration between the wavenumber limits and the peak envelope. The measurements were recorded at three temperatures, 278, 298, and $323 \mathrm{~K}$; however it is important to note that the resulting composite spectra are all scaled to a number density for $1 \mathrm{~atm}$ and 296 K. For the most part, the integrated band strengths agree among the different temperatures to within the $3 \%$ uncertainty, adding further evidence that the spectra are composed primarily of the planar s-trans conformer. There are, however, two notable exceptions. For the band integration range $1340-1220 \mathrm{~cm}^{-1}$, with $v_{14}$ and $v_{15}$, the integrated band intensity is $13 \%$ higher in the $323 \mathrm{~K}$ spectrum than it is in the $298 \mathrm{~K}$ spectrum. Similarly, in the $820-720 \mathrm{~cm}^{-1}$ range, where $v_{19}$ and $v_{29}$ are located, the $323 \mathrm{~K}$ intensity is $19 \%$ higher than in the $298 \mathrm{~K}$ spectrum. In both cases, however, there is virtually no difference between the 278 and $298 \mathrm{~K}$ spectra. Furthermore, the qualitative spectra measured at all the three temperatures compare very well to one another, and there is no evidence of extra modes or shifted peaks. Thus, while the quantitative differences may indicate a temperature dependence, it is more likely due to baseline fitting in the region of these very weak modes, rather than to an additional conformer.

Very few quantitative mid-infrared band strengths of isoprene are available in the literature, but a few pa- 


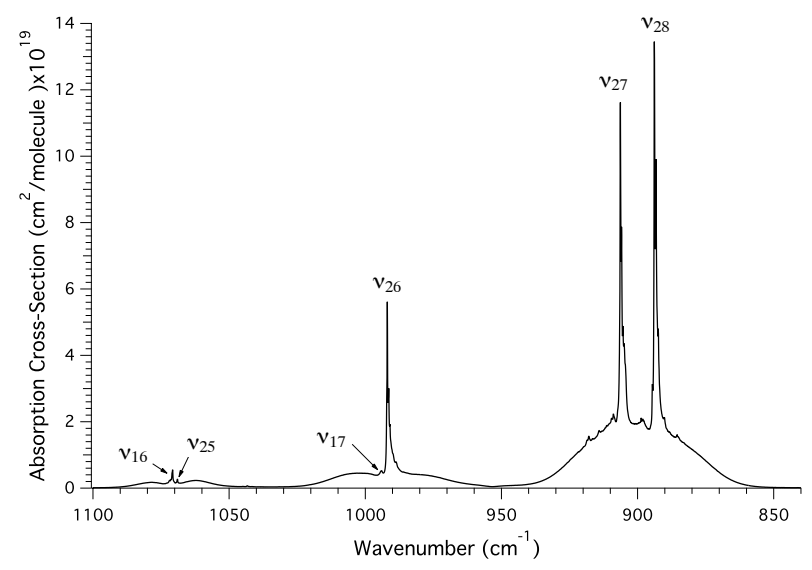

Figure 5. Quantitative infrared spectrum of isoprene from 840 to $1100 \mathrm{~cm}^{-1}$ recorded at $298 \mathrm{~K}$. Absorption cross sections are given in Naperian units $\left(\mathrm{cm}^{2}\right.$ molecule $\left.{ }^{-1}\right) \times 10^{19}$ for the composite spectrum recorded at $298 \mathrm{~K}$.

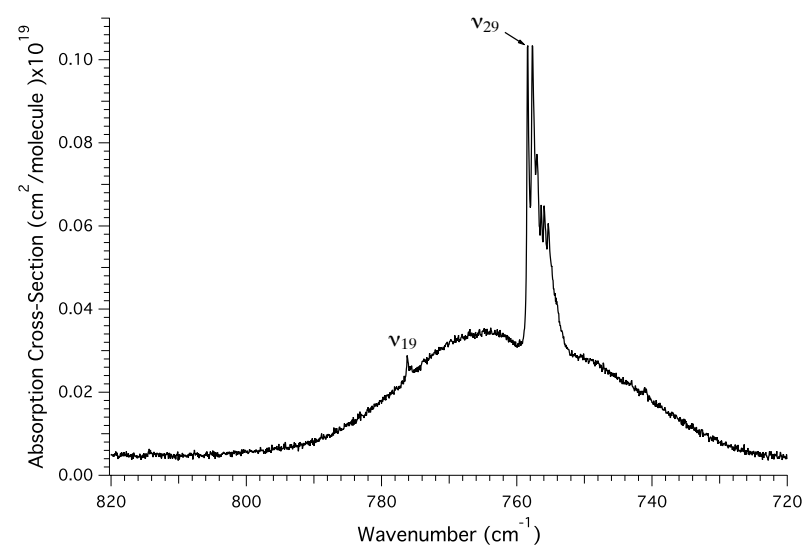

Figure 6. Quantitative infrared spectrum of $v_{19}$ and $v_{29}$ recorded at $298 \mathrm{~K}$. Absorption cross sections are given in Naperian units $\left(\mathrm{cm}^{2}\right.$ molecule -1$) \times 10^{19}$ for the composite spectrum recorded at 298 K.

pers report near-infrared absorption cross sections $(\sigma)$. For example, Cias et al. (2007) determined $\sigma$ of the $\mathrm{C}-\mathrm{H}$ overtone at $1651.52 \mathrm{~nm}\left(6055 \mathrm{~cm}^{-1}\right)$ to be $3.24( \pm 0.16) \times 10^{-22} \mathrm{~cm}^{2}$ molecule ${ }^{-1}$. Unfortunately, that mode is not observed in our spectra; thus no comparison can be made. A weak mode, however, is observed at $6155 \mathrm{~cm}^{-1}$ with $\sigma=4.5 \times 10^{-21} \mathrm{~cm}^{2}$ molecule ${ }^{-1}$. This value is $\sim 25 \%$ higher than the result reported by Denzer et al. (2011), who found $\sigma=3.6( \pm 0.2) \times 10^{-21} \mathrm{~cm}^{2}$ molecule ${ }^{-1}$ at $1624.7 \mathrm{~nm}$ $\left(6155 \mathrm{~cm}^{-1}\right)$. Given that this region is approaching the limits of our spectral range, the marginal agreement is not unexpected. In the mid-infrared, Kühnemann et al. (2002) measured the quantitative spectra of isoprene and its deuterated isotopologue, isoprene- $d_{2}$, in order to determine the detection limits of isoprene using photoacoustic spectroscopy. Their results, however, give the absorption cross sections for
Table 5. Integrated band intensities of isoprene.

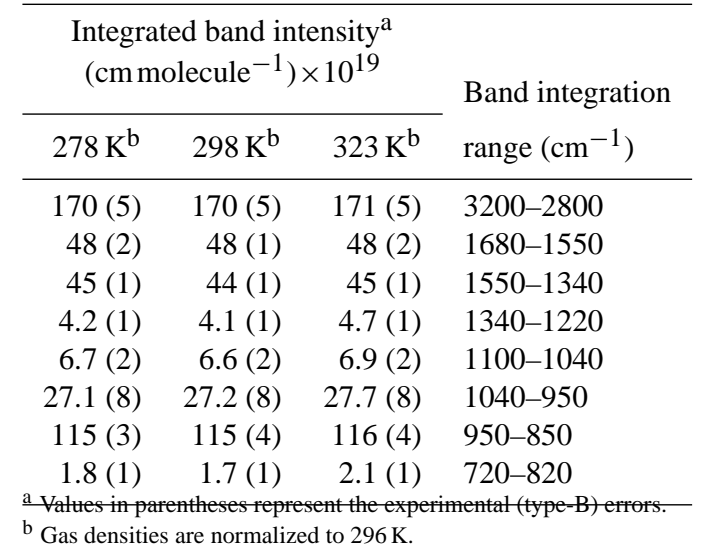

isoprene in the infrared to be almost exactly an order of magnitude larger than our measured values.

\subsection{Remote sensing considerations}

The data reported here represent the first comprehensive quantitative infrared cross sections of vapor-phase isoprene. These data allow us to conjecture as to optimal bands and theoretical detection limits for this species. For trace detection, the most obvious choice is in the 7 to $13 \mu \mathrm{m}$ longwave window. In particular, the pair of Q branches shown in Fig. 5 at 906.3 and $893.8 \mathrm{~cm}^{-1}\left(\nu_{27}\right.$ and $\left.\nu_{28}\right)$ are ideal candidates for atmospheric monitoring. Both fall within the atmospheric window (near $11 \mu \mathrm{m}$ ), and the presence of two adjacent bands of comparable intensity is useful as the two can provide further corroboration for isoprene detection. This not only reinforces the spectral assignment but also allows for higher levels of specificity of detection in atmospheric spectra, which are typically very cluttered with multiple analytes and interferents such as found in biomass burning spectra (Yokelson et al., 2013). Furthermore, the close spectral proximity of $v_{27}$ and $v_{28}$, separated by only $13 \mathrm{~cm}^{-1}$, may enable simultaneous observation of both and put them in range for observation using sensitive techniques such as quantum cascade lasers (QCLs), which can have broad tuning ranges (Hugi et al., 2009), greatly bolstering confidence and specificity for isoprene detection with infrared spectroscopy.

The differential cross section for these two modes is roughly $1.0 \times 10^{-18} \mathrm{~cm}^{2}$ molecule ${ }^{-1}$, which is $\sim 1.2 \times$ $10^{-3}(\mathrm{ppm} \mathrm{m})^{-1}$ in $\log _{10}$ units. Thus, in a $1 \mathrm{~m}$ path, an optical system with a noise level less than than $1.2 \times 10^{-3}$ would be able to detect $1 \mathrm{ppm}$ of isoprene. With a $100 \mathrm{~m}$ path length, detection of $1 \mathrm{ppbv}$ of isoprene would require $1.2 \times 10^{-4} \mathrm{OD}$ and, extrapolating further, $1 \mathrm{pptv}$ could be detected in a $100 \mathrm{~m}$ path with $1.2 \times 10^{-7} \mathrm{OD}$. In practice, however, broadband infrared methods are not this sensitive, but such sensitivities can be achieved using infrared laser techniques. 


\section{Summary}

Using moderate-resolution infrared spectroscopy combined with a multiple-burden approach, we have made quantitative measurements on the atmospherically important isoprene molecule. We have modified some vibrational assignments assuming the planar s-trans configuration, partially in agreement with prior works. The isoprene spectrum is well suited for atmospheric monitoring as it has two very strong C-type bands ( $\nu_{27}$ and $\nu_{28}$ ), both with strong cross sections, approximately $1.0 \times 10^{-18} \mathrm{~cm}^{2}$ molecule ${ }^{-1}$, and fortuitously separated by only $13 \mathrm{~cm}^{-1}$. The close proximity of the two strong bands adds much greater certainty and specificity for quantifying this species using congested mid-IR spectra.

Acknowledgements. This work was supported by the Department of Defense's Strategic Environmental Research and Development Program (SERDP), resource conservation project RC-1649. This work also was supported by the Office of Defense Nuclear Nonproliferation Research and Development (DNN R\&D), and we thank both sponsors for their support. PNNL is operated for the US Department of Energy by the Battelle Memorial Institute under contract DE-AC05-76RLO 1830.

Edited by: D. Heard

\section{References}

Adler, F., Masłowski, P., Foltynowicz, A., Cossel, K. C., Briles, T. C., Hartl, I., and Ye, J.: Mid-infrared Fourier transform spectroscopy with a broadband frequency comb, Opt. Express, 18, 21861-21872, 2010.

Akagi, S. K., Yokelson, R. J., Wiedinmyer, C., Alvarado, M. J., Reid, J. S., Karl, T., Crounse, J. D., and Wennberg, P. O.: Emission factors for open and domestic biomass burning for use in atmospheric models, Atmos. Chem. Phys., 11, 4039-4072, doi:10.5194/acp-11-4039-2011, 2011.

Akagi, S. K., Yokelson, R. J., Burling, I. R., Meinardi, S., Simpson, I., Blake, D. R., McMeeking, G. R., Sullivan, A., Lee, T., Kreidenweis, S., Urbanski, S., Reardon, J., Griffith, D. W. T., Johnson, T. J., and Weise, D. R.: Measurements of reactive trace gases and variable $\mathrm{O}_{3}$ formation rates in some South Carolina biomass burning plumes, Atmos. Chem. Phys., 13, 1141-1165, doi:10.5194/acp-13-1141-2013, 2013.

Akagi, S. K., Burling, I. R., Mendoza, A., Johnson, T. J., Cameron, M., Griffith, D. W. T., Paton-Walsh, C., Weise, D. R., Reardon, J., and Yokelson, R. J.: Field measurements of trace gases emitted by prescribed fires in southeastern US pine forests using an open-path FTIR system, Atmos. Chem. Phys., 14, 199-215, doi:10.5194/acp-14-199-2014, 2014.

Allodi, M. A., Kirschner, K. N., and Shields, G. C.: Thermodynamics of the hydroxyl radical addition to isoprene, J. Phys. Chem. A, 112, 7064-7071, doi:10.1021/jp801869c, 2008.

Barkley, M. P., Kurosu, T. P., Chance, K. V., De Smedt, I., Van Roozendael, M., Arneth, A., Hagberg, D., and Guenther, A. B.: Assessing sources of uncertainty in formaldehyde air mass factors over tropical South America: implications for top-down isoprene emission estimates, J. Geophys. Res., 117, D13304, doi:10.1029/2011JD016827, 2012.

Bock, C. W. and Panchenko, Y. N.: An ab initio structural investigation of 1,3-butadiene, isoprene and 2,3-dimethyl-1,3-butadiene rotamers, J. Mol. Struct.-Theochem., 187, 69-82, 1989.

Bock, C. W., Panchenko, Y. N., Krasnoshchiokov, S. V., and Aroca, R.: Ab initio structures and vibrational analysis of the isoprene conformers, J. Mol. Spectrosc., 160, 337-346, 1987.

Bode, B. M. and Gordon, M. S.: MacMolPlt, J. Mol. Graph. Model., 16, 133-138, 1999.

Burling, I. R., Yokelson, R. J., Griffith, D. W. T., Johnson, T. J., Veres, P., Roberts, J. M., Warneke, C., Urbanski, S. P., Reardon, J., Weise, D. R., Hao, W. M., and de Gouw, J.: Laboratory measurements of trace gas emissions from biomass burning of fuel types from the southeastern and southwestern United States, Atmos. Chem. Phys., 10, 11115-11130, doi:10.5194/acp10-11115-2010, 2010.

Burling, I. R., Yokelson, R. J., Akagi, S. K., Urbanski, S. P., Wold, C. E., Griffith, D. W. T., Johnson, T. J., Reardon, J., and Weise, D. R.: Airborne and ground-based measurements of the trace gases and particles emitted by prescribed fires in the United States, Atmos. Chem. Phys., 11, 12197-12216, doi:10.5194/acp11-12197-2011, 2011.

Campuzano-Jost, P., Williams, M. B., O’Ottone, L., and Hynes, A. J.: Kinetics of the $\mathrm{OH}$-initiated oxidation of isoprene, Geophys. Res. Lett., 27, 693-696, 2000.

Campuzano-Jost, P., Williams, M. B., D’ Otton, L., and Hynes, A. J.: Kinetics and mechanism of the reaction of the hydroxyl radical with $h_{8}$-isoprene and $d_{8}$-isoprene: isoprene absorption cross sections, rate coefficients, and the mechanism of hydroperoxyl radical production, J. Phys. Chem. A, 108, 1537-1551, 2004.

Chu, P. M., Guenther, F. R., Rhoderick, G. C., and Lafferty, W. J.: The NIST quantitative infrared database, J. Res. Natl. Inst. Stan., 104, 59-81, 1999.

Cias, P., Wang, C.-J., and Dibble, T. S.: Absorption cross-sections of the C-H overtone of volatile organic compounds: 2 methyl1,3-butadiene (isoprene), 1,3-butadiene, and 2,3-dimethyl-1,3butadiene, Appl. Spectrosc., 61, 230-236, 2007.

Compton, D. A. C., George, W. O., and Maddams, W. F.: Conformations of conjugated hydrocarbons, Part 1. A spectroscopic and thermodynamic study of buta-1,3-diene and 2-methylbuta1,3-diene (isoprene), J. Chem. Soc. Perk. T., 2, 1666-1671, doi:10.1039/p29760001666, 1976.

Denzer, W., Hancock, G., Islam, M., Langley, C. E., Peverall, R., Ritchie, G. A. D., and Taylor, D.: Trace species detection in the near infrared using Fourier transform broadband cavity enhanced absorption spectroscopy: initial studies on potential breath analytes, Analyst, 136, 801-806, doi:10.1039/c0an00462f, 2011.

Griffith, D. W. T.: Synthetic calibration and quantitative analysis of gas-phase FT-IR spectra, Appl. Spectrosc., 50, 59-70, 1996.

Guenther, A. B., Jiang, X., Heald, C. L., Sakulyanontvittaya, T., Duhl, T., Emmons, L. K., and Wang, X.: The Model of Emissions of Gases and Aerosols from Nature version 2.1 (MEGAN2.1): an extended and updated framework for modeling biogenic emissions, Geosci. Model Dev., 5, 1471-1492, doi:10.5194/gmd-51471-2012, 2012.

Hess, B. M., Xue, J., Markillie, L. M., Taylor, R. C., Wiley, H. S., Ahring, B. K., and Linggi, B.: Coregulation of terpenoid pathway genes and prediction of isoprene production in 
bacillus subtilis using transcriptomics, PLoS ONE, 8, e66104, doi:10.1371/journal.pone.0066104.s006, 2013.

Hugi, A., Terazzi, R., Bonetti, Y., Wittmann, A., Fischer, M., Beck, M., Faist, J., and Gini, E.: External cavity quantum cascade laser tunable from 7.6 to $11.4 \mu \mathrm{m}$, Appl. Phys. Lett., 95, $1-4,2009$

Jobson, B. T., Wu, Z., Niki, H., and Barrie, L. A.: Seasonal trends of isoprene, $\mathrm{C}_{2}-\mathrm{C}_{5}$ alkanes, and acetylene at a remote boreal site in Canada, J. Geophys. Res., 99, 1589-1599, 1994.

Johnson, T. J., Sams, R. L., Blake, T. A., Sharpe, S. W., and Chu, P. M.: Removing aperture-induced artifacts from Fourier transform infrared intensity values, Appl. Optics, 41, 2831-2839, 2002.

Johnson, T. J., Sams, R. L., Burton, S. D., and Blake, T. A.: Absolute integrated intensities of vapor-phase hydrogen peroxide $\left(\mathrm{H}_{2} \mathrm{O}_{2}\right)$ in the mid-infrared at atmospheric pressure, Anal. Bioanal. Chem., 395, 377-386, doi:10.1007/s00216-009-2805$\mathrm{x}, 2009$.

Johnson, T. J., Profeta, L. T. M., Sams, R. L., Griffith, D. W. T., and Yokelson, R. L.: An infrared spectral database for detection of gases emitted by biomass burning, Vib. Spectrosc., 53, 97-102, doi:10.1016/j.vibspec.2010.02.010, 2010.

Johnson, T. J., Sams, R. L., Profeta, L. T. M., Akagi, S. K., Burling, I. R., Yokelson, R. J., and Williams, S. D.: Quantitative IR spectrum and vibrational assignments for glycolaldehyde vapor: glycolaldehyde measurements in biomass burning plumes, $\mathrm{J}$. Phys. Chem. A, 117, 4096-4107, doi:10.1021/jp311945p, 2013.

Karl, T., Prazeller, P., Mayr, D., Jordan, A., Rieder, J., Fall, R., and Lindinger, W.: Human breath isoprene and its relation to blood cholesterol levels: new measurements and modeling, J. Appl. Physiol., 91, 762-770, 2001.

Karl, T., Misztal, P. K., Jonsson, H. H., Shertz, S., Goldstein, A. H., and Guenther, A. B.: Airborne flux measurements of BVOCs above Californian oak forests: experimental investigation of surface and entrainment fluxes, $\mathrm{OH}$ densities, and Damköhler numbers, J. Atmos. Sci., 70, 3277-3287, doi:10.1175/JAS-D-13054.1, 2013.

Keens, A. and Simon, A.: Correction of non-linearities in detectors in Fourier transform spectroscopy, US Patent, 1990.

Kim, S., Guenther, A. B., and Apel, E.: Quantitative and qualitative sensing techniques for biogenic volatile organic compounds and their oxidation products, Environ. Sci.: Processes Impacts, 15, 1301, doi:10.1039/c3em00040k, 2013.

Kühnemann, F., Wolfertz, M., Arnold, S., Lagemann, M., Popp, A., Schüler, G., Jux, A., and Boland, W.: Simultaneous online detection of isoprene and isoprene- $d_{2}$ using infrared photoacoustic spectroscopy, Appl. Phys. B, 75, 397-403, doi:10.1007/s00340002-0961-1, 2002.

Lide, D. R. and Jen, M.: Microwave studies of butadiene derivatives, II. Isoprene, J. Chem. Phys., 40, 252-253, doi:10.1063/1.1724886, 1964.

Mertz, L.: Auxiliary computation for Fourier spectrometry, Infrared Phys., 7, 17-23, doi:10.1016/0020-0891(67)90026-7, 1967.

Panchenko, Y. N. and De Mare, G. R.: Vibrational analysis of buta1,3-diene and its deutero and ${ }^{13} \mathrm{C}$ derivatives and some of their rotational isomers, J. Struct. Chem., 49, 235-244, 2008.

Panchenko, Y. N., Bock, C. W., Larkin, J. D., Abramenkov, A. V., and Kühnemann, F.: Predictive abilities of scaled quantummechanical molecular force fields: application to 2- methylbuta-1,3-diene (isoprene), Struct. Chem., 19, 421-428, doi:10.1007/s11224-008-9297-8, 2008.

Potosnak, M. J., LeStourgeon, L., Pallardy, S. G., Hosman, K. P., Gu, L., Karl, T., Geron, C., and Guenther, A. B.: Observed and modeled ecosystem isoprene fluxes from an oak-dominated temperate forest and the influence of drought stress, Atmos. Environ., 84, 314-322, doi:10.1016/j.atmosenv.2013.11.055, 2014.

Profeta, L. T. M., Sams, R. L., Johnson, T. J., and Williams, S. D.: Quantitative infrared intensity studies of vapor-phase glyoxal, methylglyoxal, and 2,3-butanedione (diacetyl) with vibrational assignments, J. Phys. Chem. A, 115, 9886-9900, doi:10.1021/jp204532x, 2011.

Roberts, J. M., Veres, P., Warneke, C., Neuman, J. A., Washenfelder, R. A., Brown, S. S., Baasandorj, M., Burkholder, J. B., Burling, I. R., Johnson, T. J., Yokelson, R. J., and de Gouw, J.: Measurement of HONO, HNCO, and other inorganic acids by negative-ion proton-transfer chemical-ionization mass spectrometry (NI-PT-CIMS): application to biomass burning emissions, Atmos. Meas. Tech., 3, 981-990, doi:10.5194/amt-3-981-2010, 2010.

Sharkey, T. D. and Singsaas, E. L.: Why plants emit isoprene, Nature, 374, 769, doi:10.1038/374769a0, 1995.

Sharpe, S. W., Sams, R. L., Johnson, T. J., Chu, P. M., Rhoderick, G. C., and Guenther, F. R.: Creation of $0.10 \mathrm{~cm}^{-1}$ resolution, quantitative, infrared spectral libraries for gas samples, in: Proceedings of SPIE, edited by: Christesen, S. D. and Sedlacek III, A. J., 4577, 12-24, 2002.

Sharpe, S. W., Johnson, T. J., Chu, P. M., Kleimeyer, J., and Rowland, B.: Quantitative, infrared spectra of vapor phase chemical agents, in: Proceedings of SPIE, edited by: Gardner, P. J., 5085, 19-27, 2003.

Sharpe, S. W., Johnson, T. J., Sams, R. L., Chu, P. M., Rhoderick, G. C., and Johnson, P. A.: Gas-phase databases for quantitative infrared spectroscopy, Appl. Spectrosc., 58, 1452-1461, 2004.

Squillacote, M. E. and Liang, F.: Conformational thermodynamic and kinetic parameters of methyl-substituted 1,3-butadienes, J. Org. Chem., 70, 6564-6573, doi:10.1021/jo0500277, 2005.

Stavrakou, T., Müller, J.-F., De Smedt, I., Van Roozendael, M., van der Werf, G. R., Giglio, L., and Guenther, A.: Global emissions of non-methane hydrocarbons deduced from SCIAMACHY formaldehyde columns through 2003-2006, Atmos. Chem. Phys., 9, 3663-3679, doi:10.5194/acp-9-3663-2009, 2009.

Traetteberg, M., Paulen, G., Cyvin, S. J., Panchenko, Y. N., and Mochalov, V. I.: Structure and conformations of isoprene by vibrational spectroscopy and gas electron diffraction, J. Mol. Struct., 116, 141-151, 1984.

Vickers, C. E., Gershenzon, J., Lerdau, M. T., and Loreto, F.: A unified mechanism of action for volatile isoprenoids in plant abiotic stress, Nat. Chem. Biol., 5, 283-291, doi:10.1038/nchembio.158, 2009.

Yokelson, R. J., Burling, I. R., Gilman, J. B., Warneke, C., Stockwell, C. E., de Gouw, J., Akagi, S. K., Urbanski, S. P., Veres, P., Roberts, J. M., Kuster, W. C., Reardon, J., Griffith, D. W. T., Johnson, T. J., Hosseini, S., Miller, J. W., Cocker III, D. R., Jung, H., and Weise, D. R.: Coupling field and laboratory measurements to estimate the emission factors of identified and unidentified trace gases for prescribed fires, Atmos. Chem. Phys., 13, 89-116, doi:10.5194/acp-13-89-2013, 2013. 